NBER WORKING PAPER SERIES

\title{
INCOME-BASED INEQUALITY IN EDUCATIONAL OUTCOMES: LEARNING FROM STATE LONGITUDINAL DATA SYSTEMS
}

\author{
John P. Papay \\ Richard J. Murnane \\ John B. Willett \\ Working Paper 20802 \\ http://www.nber.org/papers/w20802 \\ NATIONAL BUREAU OF ECONOMIC RESEARCH \\ 1050 Massachusetts Avenue \\ Cambridge, MA 02138 \\ December 2014
}

The research reported here was supported by the Institute of Education Sciences, U.S. Department of Education, through Grant R305E100013 to Harvard University. The opinions expressed are those of the authors and do not represent views of the Institute, the U.S. Department of Education, or the National Bureau of Economic Research. The authors thank Paul Reville for comments on an early draft, and Carrie Conaway, the Director of Planning, Research, and Evaluation of the Massachusetts Department of Elementary and Secondary Education, for providing the data and for answering many questions about data collection procedures. This paper is forthcoming in Educational Evaluation and Policy Analysis. Address correspondence to John Papay (john_papay@brown.edu).

NBER working papers are circulated for discussion and comment purposes. They have not been peerreviewed or been subject to the review by the NBER Board of Directors that accompanies official NBER publications.

(C) 2014 by John P. Papay, Richard J. Murnane, and John B. Willett. All rights reserved. Short sections of text, not to exceed two paragraphs, may be quoted without explicit permission provided that full credit, including $(\mathcal{C}$ notice, is given to the source. 
Income-based Inequality in Educational Outcomes: Learning from State Longitudinal Data Systems

John P. Papay, Richard J. Murnane, and John B. Willett

NBER Working Paper No. 20802

December 2014

JEL No. I2,I21,I24,I28

\section{ABSTRACT}

We report results from our long-standing research partnership with the Massachusetts Department of Elementary and Secondary Education. We make two primary contributions. First, we illustrate the wide range of informative analyses that can be conducted using a state longitudinal data system and the advantages of examining evidence from multiple cohorts of students. Second, we document large income-based gaps in educational attainments, including high-school graduation rates and collegegoing. Importantly, we show that income-related gaps in both educational credentials and academic skill have narrowed substantially over the past several years in Massachusetts.

John P. Papay

Brown University

Education Department

Providence, RI 02912

john_papay@brown.edu

Richard J. Murnane

Graduate School of Education

Harvard University

6 Appian Way - Gutman 469

Cambridge, MA 02138

and NBER

richard_murnane@harvard.edu
John B. Willett

Graduate School of Education

Harvard University

6 Appian Way - Gutman 412

Cambridge, MA 02138

John_Willett@harvard.edu 


\section{Income-based Inequality in Educational Outcomes: \\ Learning from State Longitudinal Data Systems}

During the first three-quarters of the $20^{\text {th }}$ century, the educational attainments of Americans increased rapidly. This remarkable trend made possible the rapid economic growth that produced a rising standard of living for most American families (Goldin \& Katz, 2008). Since the mid-1970s, the growth in educational attainments has slowed markedly, and gaps in academic achievement and educational attainments between children growing up in low-income families and those raised in more affluent families have grown (Reardon, 2011; Bailey \& Dynarski, 2011). These trends jeopardize future economic growth and the upward socioeconomic mobility of which Americans historically have been so proud.

Most of the evidence on trends in educational inequality comes from datasets such as the National Assessment of Educational Progress (NAEP), the National Longitudinal Surveys of Youth (NLSY), and the longitudinal surveys sponsored by the U.S. Department of Education. While analyses based on these datasets have provided a great deal of information about national trends, they are of very limited value in examining patterns and trends within states. This matters because the U.S. Constitution leaves the governance of public education to the states. A result is that states have developed quite varied educational systems, with differences in such dimensions as funding levels, academic standards, high school graduation requirements, and teacher licensing provisions. Consequently, inequality in educational outcomes, the sources of such inequality, and progress in remedying it may differ widely among states.

As of 2013 every state has a longitudinal data system that tracks the academic progress of every student enrolled in the state's public schools. These data systems, many of which states created quite recently with financial support from the U.S. Department of Education, provide a 
new resource for studying patterns and trends in educational outcomes within states. Moreover, a growing number of states are merging their longitudinal databases with data sources that provide information on post-secondary outcomes such as college enrollment and graduation. This ability to examine college outcomes is especially important today because post-secondary educational attainments are more important predictors of labor market earnings than they were four decades ago. Together, these longitudinal datasets that track individual students through the state educational system and into college present substantial opportunities for researchers and policymakers to understand trends in educational outcomes overall and by subgroup, and to assess the effectiveness of educational policies.

In this paper, we describe results from a seven-year-long partnership with the Massachusetts Department of Elementary and Secondary Education aimed at increasing understanding of the consequences of the state's educational reform efforts. The paper makes two kinds of contribution. First, it provides considerable evidence regarding income-based gaps in educational outcomes and especially on changes in the gaps over time. Second, it illustrates the wide-range of informative analyses that can be conducted using a state longitudinal data system.

In the next section, we describe national trends in education-related wage differentials and income-based educational inequality, as well as several factors that contribute to this inequality. We then describe our datasets and empirical approaches in more detail. We present our main results and conclude with a discussion of these findings, focusing on several key lessons for policymakers. Most of our analyses are descriptive and demonstrate important trends; where our analyses support causal inferences, we note this clearly.

\section{Income Inequality and Educational Attainments: Evidence from National Data}




\section{Educational Attainments and Labor Market Earnings}

During the 1980s, education-related wage differentials grew substantially and have remained remarkably high by historical standards. For example, in 2012, the average terminal four-year college graduate over age 25 earned 63\% more than the average terminal high school graduate, who in turn earned 38\% more than the average high school dropout, and more education is strongly related to the probability of having a full-time job (Bureau of Labor Statistics, 2012). A number of recent studies with strong causal designs show that, to a large extent, these earnings differences reflect payoffs to educational attainments rather than selfselection of the most able students to higher levels of education (cf. Card, 1999; Heckman et al., 2008). Furthermore, other recent studies have documented that additional education improves many dimensions of recipients' quality of life, including their own health and wellbeing and, in the case of women, the health of their children (Oreopoulos, 2007; Lochner \& Moretti, 2004; Lleras-Muney, 2005). Finally, obtaining more education than one's parents has been an important mechanism of upward socio-economic mobility for many generations of Americans.

\section{Educational Inequality}

There are large income-related gaps in educational attainments in the United States. For example, among students who turned 24 in 2006, those from the top quartile of family income had completed nearly four more years of schooling, on average, than those from the bottom quartile (Bailey \& Dynarski, 2011). This mirrors a strong income gradient in college access and persistence: nearly 80 percent of students in the top quartile of family income enter college by age 25, compared to just 30 percent of students in the lowest quartile. Of these students, more than two-thirds of high-income students persisted in college and graduated, compared to just under one-third of the lowest-income students (Bailey \& Dynarksi, 2011). 
These attainment patterns have resulted in rates of inter-generational socio-economic mobility in the U.S. today that are lower than those in several European countries (Jantti et al., 2006). Although the average American completes more education than his/her parents did, the proportion of students who have lower levels of educational attainment than their parents (downward mobility) is higher than it was during the 1950s and 1960s. According to Hout and Janus, "twenty-five percent of men in the late 1990s and 20 percent of men and women in the last decade were downwardly mobile, despite sharp increases in the college aspirations, expectations, and preparation of young people" (2011, p. 173). Thus, increases in educational attainments have become a less powerful driver of intergenerational social mobility than in the past.

\section{Sources of Educational Attainment Gaps}

There are large gaps present at the start of kindergarten between the average skills of students from low-income families and those from higher-income families (Duncan \& Magnuson, 2011). A number of studies show that inequalities in investments during children's first years of life contribute to these achievement gaps and that they have long-term consequences for children's life chances (Heckman et al., 2010). Inequality in family investments in children during the schooling years also contributes to income-based gaps in student achievement (Duncan \& Magnuson, 2011; Farkas, 2011). So does residential and school segregation by family income, both of which increased substantially during the last two decades of the $20^{\text {th }}$ century (Reardon \& Bischoff, 2011; Altonji \& Mansfield, 2011). The increasing concentration of low-income children in particular schools reduces the quality of education they receive through several mechanisms, including peer-group effects and the difficulty in attracting and retaining strong teaching staffs (Duncan \& Murnane, 2011; forthcoming). 
Over the past few decades, the standards-based reform movement has sought to address the vastly different levels of educational quality and rigor experienced by students in different schools. This movement has had a broad and powerful influence on education policy. About half of all states - serving nearly $70 \%$ of the nation's schoolchildren - have taken these policies one step further by requiring students to pass exit examinations in order to earn a high-school diploma (Center on Education Policy, 2012). In most states, including Massachusetts, students first take these exit examinations as $10^{\text {th }}$ graders. Because low-income students tend to score worse on these tests, they are more likely to fail the exit examinations. Students who fail have many opportunities to retake the tests and pass them. However, in part because low-income students have fewer family resources to support them and because they attend schools with large numbers of failing students, failing may present a greater barrier to high school graduation than it does for higher-income students. In Massachusetts, barely failing the $10^{\text {th }}$ grade mathematics examination reduced the probability of graduating from high-school for urban, low-income students who were in $10^{\text {th }}$ grade in 2004 (Papay, Murnane, \& Willett, 2010).

\section{Measuring Educational Attainment Gaps}

Although measuring educational attainments seems like a straightforward task, it is anything but. Most past evidence on educational attainments in the United States - including high-school graduation rates and college-going rates, as well as their predictors - derives from large, national datasets. These studies are valuable because they provide a broad-based and nationally representative picture of educational inequality. However, estimates of educational attainments from these datasets are surprisingly sensitive to the choice of data source and methodological decisions that analysts make (see Mishel \& Roy, 2006; Murnane, 2013; and Heckman \& LaFontaine, 2010 for more detailed discussion). National longitudinal surveys 
resolve some of these challenges, but they rely on self-reported data on educational credentials, which are subject to substantial measurement error, and face issues with non-random sample attrition (Murnane, 2013).

Because of these limitations, the federal government has required all states to develop longitudinal datasets that track individual students over time and enable the state to report fouryear graduation rates (US DOE, 2008). Furthermore, many states have taken additional steps, linking these data with information on post-secondary educational enrollments from the state higher education system or from the National Student Clearinghouse, an organization which tracks individual student enrollments at more than 95\% of U.S. colleges and universities.

These datasets present real opportunities for policymakers to understand educational attainment patterns in their state. Most importantly, they allow states to determine how many students entered a particular grade (such as grade 9) in a particular year. By tracking these students over time, analysts can then determine what proportion of these students graduated from high school or attended college in a set interval of time. These longitudinal state datasets thus provide more precise information about when students fall out of the educational pipeline than national surveys do.

That said, these state datasets face several important limitations, which we highlight below. Most importantly, they do not track students after they leave the public educational system of a particular state (e.g., to go to a private school or out-of-state). This raises the question of how to treat such students in calculations of statistics such as the high school graduation rate. The answer to this question can have marked impacts on estimates of high school graduation rates for particular schools and districts and for particular subgroups of 
students. Consequently, the answer is directly relevant to the design of state accountability systems.

\section{Research Questions}

This paper highlights the value of using state longitudinal datasets to shed light on income-based gaps in educational attainments, the sources of these gaps, and progress in closing them over time. We address three broad questions:

1. How do the educational attainments of Massachusetts students from low-income families compare to those of their peers from more affluent families?

2. Does information on achievement and school attachment gaps present before entry into high school account for much of the income-related gaps in educational attainments?

3. How have the educational outcomes of low-income students in Massachusetts changed over the past decade, both absolutely and relative to those of higher-income students?

\section{Data and Methods}

\section{Data and Sample}

To address our research questions, we have integrated several datasets provided by the Massachusetts Department of Elementary and Secondary Education (DESE). The process through which we obtained these administrative data may be instructive to other researchers. In 2001, DESE began the process of building a data system that would provide longitudinal information on the academic progress of all students attending the state's public schools. In 2007, DESE created an Office of Planning and Research to make better use of the data coming out of the new system to support research on a variety of questions relevant to educational policy making in the state. Recognizing that the agency had limited capacity to pursue research internally, the director of the office, Carrie Conaway, reached out to academic and research 
organizations to promote use of state data for research relevant to improving public education in the state.

We recognized the potential value of the DESE longitudinal data system and proposed to use it to study the intended and unintended consequences of standards-based reform policies in the state. The DESE supported this project because the lessons learned could prove useful to Massachusetts policymakers. The next step was to develop a Memorandum of Understanding that permitted DESE to provide us with longitudinal data on Massachusetts public school students while abiding by the provisions of the Family Educational Rights and Privacy Act, which the U.S. Congress passed in 1974. Under the terms of the MOU between DESE and Harvard University, which lawyers from the two organizations negotiated and endorsed, our group at Harvard use the DESE data only to address questions that Associate Commissioner Conaway approves. To the extent that new projects fall outside the original agreement, both sides agree to either modify the MOU or develop a new one to govern each project. We agreed to keep the data secure on encrypted computers at Harvard, which only members of our research team access, and to provide drafts of our research papers to Ms. Conaway 30 days before presenting them at conferences or submitting them to peer-reviewed journal.

The arrangement with DESE has worked out well. DESE has provided our team with annual data updates for all Massachusetts students. Ms. Conaway’s team has answered a great many questions about the data, for example, how the state assigns individuals to a graduation cohort or how exceptional cases are treated in estimating high school graduation rates. Ms. Conaway has also approved using the DESE data for a variety of projects of interest to the state, including several doctoral dissertation projects proposed by students working with us. The original MOU that we negotiated has formed the basis for collaborations that DESE has 
developed with other researchers. Importantly, the state provides these data free of charge.

Our research team has contributed in a variety of ways to the quality of the DESE data and to its constructive use. For example, we were able to secure funding to add to the DESE data system information from the National Student Clearinghouse (NSC) on post-secondary enrollment and educational attainments of Massachusetts public school students. We were also able to work with the Secretary of Education in Massachusetts to convince several public colleges and universities in the state to provide data to the NSC, and consequently to the DESE data system. DESE found the NSC data such a valuable addition to its information system that it subsequently used Department funds to pay for updates. To make the research findings more useful to state policymakers, Ms. Conaway has also instituted a policy that researchers who use state data produce a research brief appropriate for non-academic audiences. The Commissioner distributes those briefs to superintendents and principals through his weekly email to the field.

The data we obtained from DESE track students throughout their public school careers (K-12) and include unique student identifiers, state test results, demographic characteristics, school and district identifiers, and responses to surveys that students complete just before taking the state tests in $8^{\text {th }}$ and $10^{\text {th }}$ grades. This database includes all students in the state public school system. It contains information about students' educational attainments through the end of high school.

To these data, we have matched information on post-secondary attainment from the National Student Clearinghouse (NSC). The NSC merged students to the state data system using their proprietary matching algorithm that relies primarily on student names and dates of birth. This dataset indicates whether students have enrolled in college, the date of their enrollment, the name of the school they attended, and key information about the school, such as whether it is a 
two-year or a four-year institution. Thus, by combining these datasets we can track students throughout the Massachusetts public school system and through college.

Massachusetts presents a valuable case study because it is one of the highest performing school systems in the country. Since the Massachusetts Education Reform Act of 1993, which introduced standards-based reforms and state-based testing, Massachusetts has invested substantially in K-12 public education. As part of these reforms, the state began administering the Massachusetts Comprehensive Assessment System (MCAS) mathematics and English language arts (ELA) examinations in 1998. Since then, the state has been praised for having among the most rigorous academic standards in the country and examinations that align closely with these standards (Finn, Julian, \& Petrilli, 2006; Quality Counts, 2006). Furthermore, Massachusetts students are consistently among the nation's top performers on the National Assessment of Educational Progress (NAEP) examinations (NCES, 2008).

Massachusetts is also a state with a population and an economy somewhat different from much of the rest of the country. In 2007, per capita income in Massachusetts $(\$ 51,254)$ ranked third among the 50 states and its percentage of the adult population with a four-year college degree (38\%) ranked first (U.S. Census, 2009). In Figure 1, we present the monthly unemployment rate (top panel) and annual poverty rate among children (bottom panel) for Massachusetts and the United States as a whole. While both unemployment and child poverty trended up substantially starting in 2009, rates in Massachusetts remained well below national averages. These economic patterns may contribute to some of the trends in the educational attainments of Massachusetts students that we document.

In many of our analyses, we focus on students who were first-time $8^{\text {th }}$ graders in the 2003 
through 2008 school years. ${ }^{1}$ (Throughout the paper, we refer to school years by the spring of the school year.) These cohorts were scheduled to graduate from high school in 2007 through 2012. We narrow our sample to relevant years to examine longer-term educational outcomes, and we expand it when examining trends in intermediate outcomes over time. We choose $8^{\text {th }}$ grade as our baseline in most analyses because nearly all students in the state are in school in $8^{\text {th }}$ grade; students cannot drop out of school until age 16. In our primary sample, $38 \%$ of the students are low-income. These students tend to go to school in urban districts and to be from racial/ethnic minority groups: of the low-income students, 64\% attend an urban school, $19 \%$ are AfricanAmerican, 28\% are Hispanic, and 46\% are white. In comparison, $88 \%$ of higher-income students attend school in a non-urban district and 92\% are white.

\section{Measures}

We define low-income students as those eligible for a free- or reduced-price lunch, which includes those whose family income is less than 185 percent of the poverty threshold income designated by the U.S. Census Bureau. We refer to all other students as "higher income". The low-income indicator in our dataset is obviously time-varying; students can move in and out of eligibility. There is also some concern that this indicator underreports the number of low-income students in high school as students do not complete the necessary paperwork. As a result, we define students as having low family income if they are ever recorded as qualifying for the program. Thus, higher-income students are those who never qualified. It is important to keep in mind that we treat as "higher income" students who come from families with incomes just above the threshold for reduced price lunch eligibility. Thus, the contrasts we draw between the educational attainments of low-income and higher-income children are much less stark than

\footnotetext{
${ }^{1}$ The state data system began in 2002, and we use these data to identify (and exclude) any students who appear as $8^{\text {th }}$ graders in 2003 but were also in the $8^{\text {th }}$ grade in 2002.
} 
those described in national studies comparing outcomes for children from families at the $20^{\text {th }}$ and $80^{\text {th }}$ percentiles of the income distribution.

The advantage of this approach is that we may classify as low-income students who do not complete the necessary paperwork in later grades and that we more accurately identify students near the margin of the threshold as low-income. However, we may also mis-classify students as low-income whose families only had a temporary decline in income, perhaps during the recession. We find that the median low-income student in our data reported being eligible for free- or reduced-price lunch (FRPL) in 91\% of the possible reporting periods. Thus, this issue is not a major concern. In Appendix A, however, we present results with an alternative measure, classifying students as low-income if they met the FRPL standard in the majority of the periods they appeared in the dataset. The central findings are quite consistent across these alternative measures.

Our key outcomes include two measures of students' educational attainments: whether students graduated from high school and whether they attended college. We define our highschool graduation outcome directly from the state data. In each semester, the state records whether students were still enrolled in school, had dropped out, had graduated from high school, or any of a range of other outcomes (including expulsion, transferring out, etc.). ${ }^{2}$ We treat GED recipients as non-graduates (Murnane, 2013; Cameron \& Heckman, 1993). We define our college attendance outcomes using information provided by the National Student Clearinghouse for all students in the state. We measure whether students attended college, the type of college

\footnotetext{
${ }^{2}$ In some of our analyses, we focus on the group of students with defined high-school completion outcomes; in other words, we exclude students who transferred out of the Massachusetts public school system (or who died). We do this because we have no information about whether students who transferred went on to graduate from high school or not. If we include this group of students with missing high-school completion outcomes, we get nearly identical results about the magnitude of the income-related gaps, although the absolute proportions of students who graduate from high school are lower.
} 
they initially attended (two-year or four-year), and whether students graduated from college, although we can only examine this final outcome for a small proportion of students. Whenever possible, we track students' progress until six years after their cohort enters high school. For example, we track $20038^{\text {th }}$ graders through 2009. For students who progress on track with their cohort, this provides college enrollment information two years after they graduate from high school.

Our remaining predictors are standard variables from state data systems, such as student demographic characteristics, scores on state tests, and school attendance. In $8^{\text {th }}$ grade, all students took the MCAS mathematics examination; for most analyses, we standardize these scores by grade and year, although we also use scaled scores to examine trends over time. We also create a standardized measure of school attendance defined as the proportion of the school days in a particular year that the student actually attended school. ${ }^{3}$ To examine the effect of school attended, we define each student's school as the first high school that they attend after leaving $8^{\text {th }}$ grade. ${ }^{4}$ Finally, we examine student performance on the $10^{\text {th }}$ grade exit examinations. Because the state's scaled scores have such a coarse scale, with multiple raw scores mapping on to a single scaled score, we use raw scores in our main analyses. ${ }^{5}$

\section{Data-Analytic Strategy}

To examine income-related gaps in educational attainments and trends in these gaps over time, we use simple cross-tabulations. To examine the extent to which income-related gaps in

\footnotetext{
${ }^{3}$ Technically, we use as the denominator the number of days the student was in "membership" in the school system, meaning that they should have been enrolled. Thus, a student who transferred into the school system late in the year would not be counted as having poor attendance.

${ }^{4}$ Students who drop out before entering high school are included in our analysis but are coded together as having a "missing" school.

${ }^{5}$ Although multiple raw scores map to the same scaled score, each raw score corresponds to only one scaled score in a given year. For example, in 2004, all students earning 23 to 26 points received a 220. The state derives its scaled scores by using a piecewise non-linear transformation that leads to clumping of students near the scaled score thresholds. There are no such issues with the raw scores (see MA DESE, 2011, for more information on the MCAS).
} 
attainments can be accounted for by $8^{\text {th }}$ grade attendance and test scores, we fit OLS regressions of the following basic form for student $i$ :

$$
Y_{i}=\beta_{0} * \operatorname{LOWINC}_{i}+X_{i}^{\prime} \alpha+\varepsilon_{i}
$$

We include different predictors in the vector $X_{i}$ and use different measures of educational attainment as outcomes in different models. We begin with a baseline model that predicts the outcome of interest as a function of low-income status alone (i.e., we do not include any additional covariates in the model). To examine how pre-existing student characteristics affect income gaps, we add to the model students' standardized $8^{\text {th }}$ grade attendance and standardized $8^{\text {th }}$ grade mathematics score. Additional models include student demographic characteristics and school fixed effects, explicitly comparing students within the same school. We fit linear probability models for ease of interpretation, although we find nearly identical substantive results with logistic regression models.

Finally, we use a regression-discontinuity design to analyze the effect of barely failing the $10^{\text {th }}$ grade exit examination on students' educational attainments. The state assigns students to either pass or fail the exit examination on the basis of a rigidly applied cutoff score on the test. As a result, students scoring just on either side of the cutoff have similar academic skills, but are assigned to a different status (see Murnane \& Willett, 2011, and Lee \& Lemieux, 2010 for detailed discussions). In essence, we are looking for a discontinuous disruption in the probability of earning each educational attainment for students on either side of the cut score.

We implement this regression-discontinuity design using the approach laid out by Imbens \& Lemieux (2008) and described in detail for this particular context in our previous work (Papay, Murnane, \& Willett, 2010). We re-center the raw test scores by subtracting out the value of the corresponding minimum passing score such that a student with a score of zero had 
achieved the minimum passing score. We use local-linear regression analysis and focus attention on students who fall in a narrow window around the cut score. We also seek to understand whether the effect of barely failing these exit examinations has changed over time in the state. Here, we estimate the regression-discontinuity model described above for each three-year period (given the limited sample of low-income students, we focus on three-year windows), essentially looking at a "moving average" effect of failing within each period.

\section{Educational Attainment Gaps}

In Massachusetts, higher-income students graduate from high school, attend college, and persist in college at greater rates than their low-income peers. In Figure 2, we present the proportion of low-income and higher-income $8^{\text {th }}$ graders in Massachusetts (in 2003 through 2006) who graduated from high school, attended college, and attended a four-year college within two years after their cohort graduated from high school. Clearly, the distribution of educational attainments heavily favors students with higher family incomes, and the income gaps increase as attainments rise: there is a 20 percentage-point gap in high school graduation rates, a 31 percentage-point gap in college-going, and a 39 percentage-point gap in four-year college attendance. Nearly $65 \%$ of higher-income $8^{\text {th }}$ graders go on to attend a four-year college, compared to fewer than $25 \%$ of low-income students. Among the $20038^{\text {th }}$ graders, the cohort we can follow the longest, 37\% of higher-income students graduated from a four-year college within four years of their cohort's high school graduation compared to just $8 \%$ of low-income students.

\section{Explaining Gaps in Educational Attainment}

Identifying these gaps in educational attainments raises the question of why they arise. We describe three stylized facts about low-income students in Massachusetts and provide evidence - both descriptive and causal - about how they contribute to income-related attainment 
gaps. In particular:

(1) Low-income students enter high school with much weaker skills (as measured by test scores) and poorer school attendance than higher-income students.

(2) Low-income students tend to attend high schools serving primarily other low-income students.

(3) Low-income students perform worse on high-school exit examinations than higher-income students.

Pre-existing differences in achievement and attachment to school

Low-income students have much lower test scores and are absent much more frequently than their higher-income peers. The median $8^{\text {th }}$ grade mathematics score of low-income students is equal to the $16^{\text {th }}$ percentile score among higher-income students. Similar patterns emerge in $8^{\text {th }}$ grade attendance; here, low-income students lag behind higher-income students by 0.45 standard deviations, equivalent to approximately one additional week of school. By and large, these gaps do not suddenly emerge in $8^{\text {th }}$ grade, but have existed since elementary school.

Clearly, many factors contribute to income-related educational attainment gaps. These begin at the time of conception and include many things outside the control of schools, such as nutrition, health care, and myriad experiences within and later outside the family. Not even the richest of longitudinal datasets capture more than a small portion of the relevant influences. Our strategy is simply to ask what proportion of income-based gaps in educational attainments can be accounted for by differences in pre-high school experiences that are summarized in grade 8 math scores and attendance.

In the left hand bar of each set of bars in Figure 3, we illustrate the income gap in one measure of educational attainment: high school graduation, college attendance, or 4-year college 
attendance. The subsequent bars in each set illustrate the extent to which differences between low-income students and higher-income students in $8^{\text {th }}$ grade mathematics achievement, attendance, school attended, and other student demographic characteristics account for the income-based gaps. Differences in $8^{\text {th }}$ grade math achievement alone account for $1 / 3$ to $1 / 2$ of the attainment gaps. Notice that attendance patterns add explanatory power over and above the impact of $8^{\text {th }}$ grade test scores, suggesting the importance of attachment to school. ${ }^{6}$

\section{Differences among high schools}

One factor that may account for income-based gaps in educational attainments among students with the same grade 8 math scores and attendance are differences in the high schools they attend. Indeed, as illustrated by comparing the heights of the third and fourth bars in each set in Figure 3, differences among high school attended do account for a small proportion of the income-based gap in each of the three educational attainment measures. However, more than one-third of the income-based gap in each of the educational attainment measures consists of differences among students with the same grade 8 mathematics score and attendance who attend the same high school.

Importantly, demographic characteristics (such as a student's race, gender, age, English proficiency status, and special education status) explain very little of the remaining incomebased gaps in educational attainments, when estimated in a model that controls for $8^{\text {th }}$ grade math achievement, $8^{\text {th }}$ grade attendance, and high school attended. In other words, these income-based gaps do not simply reflect the effects of student race or other standard demographic characteristics. Instead, as indicated by the height of the right-most bar in each set, many unobserved factors, including the conditions of poverty, contribute to income-related gaps in

\footnotetext{
${ }^{6}$ Since grade 8 math scores, attendance, and student demographic characteristics are correlated, the contribution of each in accounting for the income-related gap in attainment depends on the order in which the variables are added to the model.
} 
educational attainments, particularly in post-secondary enrollment.

A complementary way of examining income-based gaps in educational attainments is to explore whether the size of the gap is different for students who enter high school with strong skills than for those who enter with relatively weak skills. In Figure 4, we present rates of highschool graduation, college-going, and four-year college-going for low-income and higherincome students at the $10^{\text {th }}, 25^{\text {th }}, 50^{\text {th }}, 75^{\text {th }}$, and $90^{\text {th }}$ percentiles of the $8^{\text {th }}$ grade state mathematics test-score distribution. ${ }^{7}$ The bottom part of each bar represents the proportion of low-income students scoring at that percentile who attain the outcome within two-years after their cohort graduates from high school. The full bar represents the same value for higher-income students, so the striped area represents the income-based gap. We see strikingly different patterns across the test-score distribution and across outcomes, suggesting that different margins are at play at different parts of the distribution. For example, there is a large gap of nearly $19 \%$ points in highschool graduation rates among students with very weak $8^{\text {th }}$ grade skills, but this gap narrows with student performance such that there is no gap among students at the $90^{\text {th }}$ percentile. In contrast, among students at the $90^{\text {th }}$ percentile, there are quite large gaps in four-year college-going. For both college-going and four-year college-going, gaps are largest near the middle of the test-score distribution, reaching a maximum of more than $20 \%$ points among students scoring at the median.

\section{High School Exit Examinations}

Income-based gaps in educational attainments are present even among students who express plans to attend college. Of students who take the $10^{\text {th }}$ grade examinations, a large majority $-82 \%$ of low-income students and $90 \%$ of higher-income students - say they plan to

\footnotetext{
${ }^{7}$ For precision, we include all students within 0.05 standard deviations on either side of the relevant percentile in each year.
} 
continue to post-secondary education. ${ }^{8}$ While the income gap in college-going plans is only 8 percentage points, the gap in actual college attendance is 30 percentage points. Among students who report college-going plans in $10^{\text {th }}$ grade, only $59 \%$ of low-income students actually do attend (within two years of their cohort's high-school graduation), compared to $82 \%$ of higherincome students. Thus, there are substantial barriers to college attendance even among students who remain in school through $10^{\text {th }}$ grade and think that they are on target to attend college.

For most high-school students, matriculating to college requires them to graduate from high school by passing a sufficient number of courses and demonstrating proficiency on state exit examinations in mathematics and English language arts. Exit examinations increase the cost of graduation for students who fail them because they must retake and pass the examinations. This is not much of a concern for most higher-income students, as $94 \%$ of these students pass both tests on their first try. However, 23\% of low-income students fail at least one of these tests, and almost $8 \%$ fail both, on the first attempt. Thus, because low-income students perform worse on these tests, the exit examinations are more likely to pose an obstacle to graduation for them.

Importantly, identifying group differences between students who pass and those who fail does not provide causal evidence that failing an exit examination presents a barrier to graduation. Students who fail the examination have, on average, much lower academic proficiency and presumably would have had a much greater probability of dropping out even in the absence of an exit examination requirement. We can, however, exploit the natural experiment presented by the state's assignment of students to pass or fail the test using a sharp cutoff to draw causal inferences about the effect of passing the test for students scoring near the cutoff. Using a regression-discontinuity design and data from the 2003 through $200910^{\text {th }}$ grade cohorts, we

\footnotetext{
${ }^{8}$ Of course, this question asks only about students' educational plans and not about their preparation or understanding of the preparation necessary to attend college.
} 
compare the outcomes of students with essentially equal proficiency but who fall just on either side of the cut score. We focus our attention on mathematics because most students who fail an exit examination fail this exam. ${ }^{9}$

Because we have reported similar results elsewhere (Papay, Murnane, \& Willett, 2010; Papay, Murnane, \& Willett, 2014), we simply illustrate key findings here, using more cohorts of data than were available to us in the past. In Figure 5, we show the fitted local linear regression over the sample average probabilities of graduating or attending college. Even among students with the same $10^{\text {th }}$ grade test score, low-income students have much lower probabilities of graduating from high school or attending college. Furthermore, the effect of barely failing the test is much greater for low-income students. This is represented by the jump in the fitted probability at the cut score. For low-income students, barely failing the test reduces the probability of graduation in five years by 2.8 percentage points $(\mathrm{p}<0.001)$ and decreases the probability of attending college within two years of cohort graduation by 3.5 percentage points $(p=0.012)$. Barely failing the exit examination does not reduce the probability of high school graduation or college enrollment for higher-income students.

\section{Trends over Time}

Thus far, we have documented large income-based gaps in educational attainments and identified several important determinants of these gaps. From a policy perspective, though, a critical question is whether attainments and gaps are increasing or decreasing. Longitudinal state datasets enable researchers to look within the system for evidence of progress. Examining educational attainments is particularly useful because of the well-known limitations of examining trends in state test scores over time (see Koretz, 2008).

\footnotetext{
${ }^{9}$ We have discussed elsewhere the opportunities and limitations of examining in the same analysis the effects of failing either or both of the exit examinations (Papay, Murnane, \& Willett, 2011; 2014).
} 


\section{Trends in Educational Attainments}

Over the past decade, as Massachusetts has made substantial public investments in support of its standards-based reform strategy, educational attainments for both low-income students and higher-income students have increased. Moreover, income-based gaps in attainments have grown smaller.

In Panel A of Figure 6, we display income-related gaps in high-school graduation rates measured four, five, and six years after students enter high school. This figure reveals two important patterns. First, income-related gaps in high school graduation rates have declined substantially over the time period we examine. The gap in four-year graduation rates has fallen from 27 percentage points for students who were in $8^{\text {th }}$ grade in 2003 to 22 percentage points for the cohort of $8^{\text {th }}$ graders in 2008 . This represents nearly a $20 \%$ reduction. Second, this figure shows the limitation of using 4-year graduation rates to measure educational attainments. The income-based gaps in six-year high school graduation rates are much smaller than the gaps in four-year or "on-time" graduation rates. This is because low-income students are much more likely than higher-income students to take more than four years to graduate from high school. In fact, $12 \%$ of all low-income students who graduate from Massachusetts public schools take more than four years to do so, compared to just 3\% of higher-income students. As a result, the incomerelated gap in six-year graduation rates is more than $20 \%$ smaller than the gap in four-year graduation rates.

Importantly, the narrowing gaps over time seen in panel A do not fully reflect the improvement in graduation rates for low-income students because the graduation rate of higherincome students in the state has also increased. In panel B, we illustrate this trend, showing the improvement in overall four-year graduation rates for low-income students and higher-income 
students. We choose four-year rates, despite their limitations, because they enable us to examine more cohorts. We present two estimates of the four-year graduation rate in each bar. The solid portion represents what we call the "raw" graduation rate, simply the proportion of students in each $8^{\text {th }}$ grade cohort who are known to graduate on-time with their cohort. In other words, 52\% of Massachusetts low-income $8^{\text {th }}$ graders in 2003 graduated from a Massachusetts public high school four years later in 2007, and $79 \%$ of higher-income students in this $8^{\text {th }}$ grade cohort did so. This figure necessarily understates the true graduation rate because it includes students in the denominator who may not belong there - namely students who are recorded in the database as having left the Massachusetts public school system prior to graduation, either by transferring to a private school (or to home schooling) or who left the state. The striped section of each bar adjusts the graduation rate by removing from the denominator students who, according to information provided by high schools, fall into this category. ${ }^{10}$ However, to the extent that students may be misclassified as transfers, the full bars may overstate the actual graduation rate. Regardless, though, we see attainments increasing for both groups.

Given that our college-going data derives from a national dataset, the transfer issue is less important for analyses of college enrollment. In Panel C, we present results on trends in collegegoing, showing the proportion of low-income students (solid bar) and higher-income students (total bar) who enroll in college one and two years after cohort graduation. The pattern is similar to the high-school graduation patterns: the gaps are smaller when students have more time to take the next step, attainments are rising, and income-based gaps are narrowing over time. For example, the percentage of low-income students enrolling in college within two years of their cohort's scheduled high school graduation was 6 percentage points higher for the 2006 grade 8 cohort than for the 2003 cohort (an increase of nearly 15 percent), and the income gap was 2

\footnotetext{
${ }^{10}$ The small number of students who died while in high school also fall into this category.
} 
percentage points lower for the later cohort than for the earlier one.

\section{Trends in Intermediate Educational Outcomes}

We can gain additional insight about educational progress by examining trends in intermediate educational outcomes, namely, test scores, attendance, and course selection. If schools are becoming more effective, such outcomes should also be improving and gaps should be narrowing. Test scores are rising for both low-income and higher-income students, and again low-income students are catching up. ${ }^{11}$ We can see this pattern clearly by examining test-score distributions for each group over time. In Figure 7, we present Quantile-Quantile (QQ) plots that show the relationship between two test-score distributions. For example, in Panel A, we compare the 2003 and $20118^{\text {th }}$ grade mathematics test-score distributions for low-income students. Each point represents a particular quantile on the distributions. The dashed lines illustrate that a lowincome student scoring 240 in 2011 (the "Proficiency" cutoff) is at the same point in the lowincome score distribution as a low-income student scoring 224 in 2003 (just barely above the "Needs Improvement" cutoff). ${ }^{12}$ In Panel B, the dashed lines illustrate that a higher-income student scoring 240 in 2011 (the "Proficiency" cutoff) is at the same point in the higher-income score distribution as a higher-income student scoring 230 in 2003. The diagonal line indicates the pattern we would see if the two distributions were identical. As such, the degree to which the plot differs from this diagonal line indicates how different the two distributions are.

Trends in attendance also show improvement for both low-income and higher-income students and gaps closing over time. In 2003, the gap was over 3 percentage points, or about 5.5

\footnotetext{
${ }^{11}$ Over the past two decades, Massachusetts students have also exhibited substantial achievement growth on the National Assessment of Educational Progress (NAEP). This growth has been more rapid - for all students and for low-income students - than in the rest of the nation. However, we do not focus on gaps in the NAEP for several reasons. First, the test is not aligned to the state standards in Massachusetts. Second, the definition of low-income students is different than the one we use throughout the paper.

${ }^{12}$ This corresponds to the $69^{\text {th }}$ percentile, although the exact mapping to percentiles is not apparent from the chart.
} 
days. By 2011, attendance for both low-income and higher-income students had improved and the gap narrowed by $14 \%$, or about one day a year. In total, these patterns contributed to the average low-income $8^{\text {th }}$ grader attending school by 2.6 more days in 2011 than in 2003.

Finally low-income students are taking more advanced courses earlier in high school. Based on data from surveys that students took when they complete their state testing, 29\% of low-income students in the $10^{\text {th }}$ grade in 2003 were in Algebra I or General Math in $10^{\text {th }}$ grade. By 2011, only $10 \%$ of low-income $10^{\text {th }}$ graders were in such courses. Furthermore, in 2011, nearly $30 \%$ of low-income $10^{\text {th }}$ graders enrolled in Algebra II, compared to just $14 \%$ in $2003 .{ }^{13}$

\section{Test Score Gaps by Time in the Public School System}

Further evidence that students' educational histories affect their eventual attainments and that Massachusetts schools are succeeding in narrowing achievement gaps - comes from examining how the performance of students changes as they spend more time in the state's public school system. In Figure 8, we present the income-related mathematics test-score gap in grades 4, 6, 7, 8, and 10 (the years for which we have a sufficiently long panel of test data). Each line represents students who entered the Massachusetts public school system in a particular grade and stayed through $10^{\text {th }}$ grade. For example, the bottom line shows the income-based gap in test scores for students who entered in grade 4, pooled across cohorts. ${ }^{14}$ Notice that we are comparing low-income and higher-income students who arrived in the system in the same grade and who stayed through $10^{\text {th }}$ grade.

We find striking patterns. The downward slope of each of the lines in Figure 8 illustrates that the achievement gap between low-income and higher-income students closes the longer

\footnotetext{
${ }^{13}$ These patterns of high-school course-taking are not as definitive as other trends measured in $8^{\text {th }}$ grade, because they could reflect changes in high-school dropout behavior. However, given that attainments are increasing throughout this period, we believe these reflect, if anything, an understatement of the shifts in course-taking.

${ }^{14}$ Each line provides score trends for a common sample of students, those who have non-missing test scores in each of the tested grades. The patterns look similar when we look at all relevant students in a particular grade.
} 
students spend in the state's public school system. ${ }^{15}$ For example, among students who entered the system in $4^{\text {th }}$ grade, the gap narrowed from $0.94 \mathrm{SD}$ in $4^{\text {th }}$ grade to $0.68 \mathrm{SD}$ in $10^{\text {th }}$ grade, a reduction of more than 0.25 SD. Among students who entered the system in $8^{\text {th }}$ grade, the gap narrowed from $1.16 \mathrm{SD}$ to $0.95 \mathrm{SD}$ in two years. ${ }^{16}$

Trends in the Effects of Educational Accountability

As illustrated in the top panel of Figure 9, low-income students are passing the $10^{\text {th }}$ mathematics and English language arts exit examinations on their first attempt at much higher rates than they were ten years ago, and the income-based gap in passing rates has narrowed substantially. In 2003, 87\% of higher-income students passed both tests on their first try, compared to just $56 \%$ of low-income students, a gap of more than 30 percentage points. By 2011, this gap had narrowed to 12 percentage points. This trend does not reflect substantial shifts in the test-taking population: among $20038^{\text {th }}$ graders with low family income, $76 \%$ continued on to take the $10^{\text {th }}$ grade exit examinations; among the $20088^{\text {th }}$ grade cohort, the comparable figure was $80 \%$. Indeed, given the negative correlation between family income and test scores, these patterns should produce a trend in the opposite direction.

One consequence of the improvement in the academic performance of $10^{\text {th }}$ graders over the last decade is that that the exit examination requirement has become an obstacle to graduation for fewer low-income students in recent cohorts than in earlier cohorts. But what

\footnotetext{
${ }^{15}$ There are several possible explanations for the vertical separation of the lines, which indicate that income-related test-score gaps are larger for students who arrive in the state school system later in the schooling careers. Most obviously, low-income students who arrive in the state later in their careers may be different than those who arrive earlier. Students who appear in our Grade 3 comparison are those who entered the state in $3^{\text {rd }}$ grade and whose families remained until $10^{\text {th }}$ grade. By contrast, those in the Grade 8 comparison entered in $8^{\text {th }}$ grade and stayed through $10^{\text {th }}$ grade. It is likely that, on average, students who enter in $8^{\text {th }}$ grade are more mobile. While this analysis controls explicitly for differential mobility within each line, it does not do so across lines.

${ }^{16}$ In theory, this pattern could also result from higher-income students hitting the test-score ceiling earlier than lowincome students. However, in practice, for the sample of students who arrive in the state in grade 4 or beyond, this is not a concern because very few of these students hit the test score ceiling. For example, on the grade 10 test, fewer than 10 students who enter the state in any of these cohorts, or less than $0.4 \%$ of the sample for a given cohort, hit the ceiling.
} 
about those low-income students who did fail the $10^{\text {th }}$ grade MCAS mathematics examination?

(Recall that just failing this examination lowered the probability of graduation by 2.8 percentage points for low-income students in the 2003 to $200910^{\text {th }}$ grade cohorts.) Are high schools better able to support struggling students today than they were a decade ago? To answer this question, we fit the regression-discontinuity model in equation (1) for a moving three-year window across the years in our data. In the bottom panel of Figure 9, we plot the estimated effects of barely passing the examination (instead of barely failing it) on the probability that low-income students graduate from high school within five years of their cohort entering high school. We plot these effects for each year, using the middle of the three-year moving window in each case. ${ }^{17}$ As the figure illustrates, the estimated effect of barely failing the test for low-income students fell from approximately 4 percentage points in 2004 to 1 percentage point or less in 2008. Thus, failing the test poses less of a hurdle to graduation for low-income students today than it did several years ago. $^{18}$

\section{Conclusion}

That low-income children in the United States have much lower achievement and lower educational attainments, on average, than higher-income students has been well documented. Indeed, this is one of the principal findings of the "Coleman Report," published in 1966. As mentioned above, both family-related and school-related factors contribute to this pattern. A

\footnotetext{
${ }^{17}$ We estimate three different versions of each effect, from models where we use bandwidths for our local linear regression analysis of 3, 4, and 5 score points, and find quite similar results in each case.

${ }^{18}$ We can only speculate about why the effect of failing for students on the margin of passing has fallen over time. One possible explanation is that students are now doing much better on the $10^{\text {th }}$ grade examination. As a result, the students who are on the margin of passing are now drawn from further in the tail of the test-score distribution. For example, the average $8^{\text {th }}$ grade mathematics score of low-income students within three points of the cutoff on the $10^{\text {th }}$ grade test in 2008 is more than 0.3 standard deviations lower than such students near the cutoff in 2004 . An alternative explanation is that the improvement in performance has reduced the number of failing students that schools need to serve. For the average low-income student near the cutoff in 2004, 26\% of her peers in the school failed the test. By 2008, that figure had fallen to $16 \%$. Finally, schools and districts may be more successful in providing remediation and support to students who fail.
} 
difficult question is how schools can do a better job of educating low-income children and perhaps even level somewhat the playing field on which they compete with higher-income children.

There are many stories in the media and even some quantitative studies of individual schools that have improved the achievement and educational attainments of low-income students markedly. ${ }^{19}$ However, to our knowledge, until quite recently there have been no systematic analyses of the success of a state school system in closing income-based gaps in academic achievement and educational attainments. One reason is that the requisite data were not available. Now almost all states have data systems that track the academic progress of students in public schools. In this paper we show how these data can support a wide range of analyses that shed light on the nature of income-based gaps in educational attainments and progress in closing these gaps.

We document large gaps in educational attainments between low-income and higherincome students in Massachusetts. These gaps become greater at higher levels of attainment. We show that low-income students arrive in high school lagging behind their higher-income peers in test scores and school attendance, and they attend different schools. However, even when we compare students in the same high school with similar characteristics, $8^{\text {th }}$ grade test scores, and $8^{\text {th }}$ grade attendance, large gaps in subsequent attainments remain. Differential responses to the state's exit examination policy may account for part of this remaining gap, as low-income students perform much worse on these tests and barely failing them reduces attainments more for low-income students than from higher-income students. But, clearly the effects of poverty (or its correlates) produce substantial disadvantages in educational attainments for low-income youth.

Importantly, we also document clear signs of progress over the past decade as educational

\footnotetext{
${ }^{19}$ See, for example, Dobbie \& Fryer (2011) and Angrist et al. (2010).
} 
attainments of low-income students in Massachusetts have increased and income-based gaps in attainments have closed substantially. This pattern contrasts with the national trend of increasing income-based inequality in educational outcomes that Reardon (2011) has documented. In summary, the analyses we conducted provide evidence that the educational system in Massachusetts has made substantial progress in reducing educational inequalities and in improving the life chances of low-income students. Of course, the analyses also show much more work remains in the effort to provide all Massachusetts public schools with the skills and educational attainments they will need to thrive in $21^{\text {st }}$ century America.

We close with three suggestions for other researchers conducting analyses of educational attainments using state longitudinal databases. The first is to recognize that disadvantaged students often take longer than other students in reaching educational goals, including high school graduation. Consequently, gaps between disadvantaged students and other students in reaching academic goals "on time" will be larger than gaps measured one or two years later than "on time." Furthermore, in examining the effects of educational interventions on students' attainments, researchers should recognize that understanding the ultimate effects may require a relatively long time horizon, particularly for low-income students.

Second, there is great value in examining trends over time. For example, analysis of any one of the cohorts of Massachusetts students in the last decade would have shown substantial gaps in attainments between low-income and higher-income students. While no surprise, given the history of such patterns, the results for a single cohort might suggest that the substantial Massachusetts investments in public education over the past two decades have not borne fruit. The analyses of trends in attainments that we present tell a quite different story.

Third, good research always raises new questions and consequently it is useful to plan a 
program of research rather than a single study. State longitudinal datasets, such as the one we examine, provide invaluable information in developing such a program. In our case, further questions include some that can be addressed with more finer-grained analysis, such as whether the progress that we documented takes place throughout the state's 300 districts or has been concentrated in a subset of districts. However, even the best dataset leaves many open questions: Did the progress stem from observable changes in the day-to-day experiences of low-income students in Massachusetts public schools? What combination of policies produced these changes? Understanding the sources of the improvement in the schooling of low-income students will require detailed analysis of the school-level and classroom-level practices that have facilitated it, research quite different from the analyses described in this paper. 


\section{References}

Altonji, J.G., \& Mansfield, R.K. (2011). The role of family, school, and community characteristics in inequality in education and labor-market outcomes. In G.J. Duncan \& R.J. Murnane, eds., Whither Opportunity? Rising Inequality, Schools, and Children's Life Chances. New York: Russell Sage Foundation.

Angrist, J.D., Dynarski, S.M., Kane, T.J., Pathak, P.A., \& Walters, C.R. (2010). Inputs and impacts in charter schools: KIPP Lynn. American Economic Review Papers and Proceedings, 100(May), 1-5.

Bailey, M.J., \& Dynarski, S.M. (2011). Inequality in post-secondary education. In G.J. Duncan \& R.J. Murnane, eds., Whither Opportunity? Rising Inequality, Schools, and Children's Life Chances. New York: Russell Sage Foundation.

Bureau of Labor Statistics. (2012). Earnings and unemployment rates by educational attainment. Retrieved September 17, 2013 from http://www.bls.gov/emp/ep_table_001.htm

Cameron, S.V., \& Heckman, J.J. (1993). The nonequivalence of high school equivalents. Journal of Labor Economics, 11(1), 1-47.

Card, D. (1999). The causal effect of education on earnings. In O. Ashenfelter and D. Card, eds. Handbook of Labor Economics, Volume 3. Amsterdam: Elsevier.

Center on Education Policy. (2012). State high school exit exams: A policy in transition. Washington, DC: George Washington University Center on Education Policy.

Coleman, J.S., et al. (1966). Equality of Educational Opportunity. Washington: U.S. Office of Education.

Dobbie, W., \& Fryer, R.G. (2011). Getting beneath the veil of effective schools: Evidence from New York City. National Bureau of Economic Research Working Paper \#17632.

Duncan, G.J. \& Magnuson, K. (2011). The nature and impact of early achievement skills, attention skills, and behavior problems. In G.J. Duncan \& R.J. Murnane, eds., Whither Opportunity? Rising Inequality, Schools, and Children's Life Chances. New York: Russell Sage Foundation.

Duncan, G.J., \& Murnane, R.J., eds. (2011). Whither Opportunity? Rising Inequality, Schools, and Children's Life Chances. New York: Russell Sage Foundation.

Duncan, G.J., \& Murnane, R.J.. (forthcoming). Restoring Opportunity: The Crisis of Inequality and the Challenge for American Education. Cambridge, MA: Harvard Education Press and Russell Sage.

Farkas, G. (2011). Middle and high school skills, behaviors, attitudes, and curriculum enrollment, and their consequences. In G.J. Duncan \& R.J. Murnane, eds., Whither Opportunity? Rising Inequality, Schools, and Children's Life Chances. New York: Russell Sage Foundation.

Finn, C.E., L. Julian, \& Petrilli, M.J. (2006). The state of state standards. Washington, D.C.: The Fordham Foundation.

Goldin, C. \& Katz, L.F. (2008). The Race between Education and Technology. Cambridge, MA: Belknap Press.

Heckman, J.J., Lochner, L.J., \& Todd, P.E. (2008). Earnings functions and rates of return. Journal of Human Capital, 2(1), 1-31.

Heckman, J.J., Moon, S.H., Pinto, R., Savelyev, P.A., \& Yavitz, A. (2010). The rate of return to the HighScope Perry Preschool Program. Journal of Public Economics, 94(1-2), 114-128.

Hout, M. \& Janus, A. (2011). Educational mobility in the United States since the 1930s. In G.J. Duncan \& R.J. Murnane, eds., Whither Opportunity? Rising Inequality, Schools, and 
Children's Life Chances. New York: Russell Sage Foundation.

Imbens, G., \& Lemieux, T. (2008). Regression discontinuity designs: A guide to practice. Journal of Econometrics, 142(2), 615-35.

Jäntti, M., Røed, K., Naylor, R., Björklund, A., Bratsberg, B. Raaum, O., Österbacka, E., \& Eriksson, T. (2006). American exceptionalism in a new light: A comparison of intergenerational earnings mobility in the Nordic countries, the United Kingdom and the United States. IZA Discussion Paper \#1938.

Koretz, D.M. (2008). Measuring up: What educational testing really tells us. Cambridge, MA: Harvard University Press.

Lee, D.S. \& Lemieux, T. (2010). Regression Discontinuity Designs in Economics. Journal of Economic Literature, 48(2), 281-355.

Lleras-Muney, A. (2004). The relationship between education and adult mortality in the United States. Review of Economic Studies, 72(1).

Lochner, L., \& Moretti, E. (2004). The effect of education on crime: Evidence from prison inmates, arrests, and self-reports. American Economic Review, 94(1), 155-189.

Massachusetts Department of Education. (2011). 2011 MCAS and MCAS-Alt technical report. Retrieved August 8, 2013 from http://www.mcasservicecenter.com/McasDefault.asp?ProgramID=31.

Murnane, R.J. (2013). U.S. high school graduation rates: Patterns and explanations. Journal of Economic Literature, 51(2), 370-422.

Murnane, R.J. \& Willett, J.B. (2011). Methods matter: Improving causal inference in educational and social science research. New York: Oxford University Press.

National Center for Education Statistics. (2008). State comparisons: National Assessment of Educational Progress (NAEP). Washington, DC: U.S. Department of Education. Retrieved April 5, 2008 from http://nces.ed.gov/nationsreportcard/nde/statecomp/

Oreopoulos, P. (2007). Do dropouts drop out too soon? Wealth, health, and happiness from compulsory schooling. Journal of Political Economy, 91, 2213-2229.

Papay, J.P., Murnane, R.J., \& Willett, J.B. (2014). High-school exit examinations and the schooling decisions of teenagers: A multi-dimensional regression-discontinuity analysis. Journal of Research on Educational Effectiveness, 7(1), 1-27.

Papay, J.P., Willett, J.B., \& Murnane, R.J. (2011). Extending the regression-discontinuity approach to multiple assignment variables. Journal of Econometrics, 161(2), 203-207.

Papay, J.P., Murnane, R.J., \& Willett, J.B. (2010). The consequences of high school exit examinations for low-performing urban students: Evidence from Massachusetts. Educational Evaluation and Policy Analysis, 32(1), 5-23.

Quality Counts. (2006). Quality Counts at 10: A decade of standards-based education. Education Week, 25(17), 74.

Reardon, S.F. (2011). The widening academic achievement gap between the rich and the poor: New evidence and possible explanations. In G.J. Duncan \& R.J. Murnane, eds., Whither Opportunity? Rising Inequality, Schools, and Children's Life Chances. New York: Russell Sage Foundation.

Reardon, S.F., \& Bischoff, K. (2011). Income inequality and income segregation. American Journal of Sociology, 116(4), 1092-1153.

U.S. Census Bureau (2009). The 2010 statistical abstract: The national data book. Washington, DC: Author. Retrieved October 28, 2010 from http://www.census.gov/compendia/statab/rankings.html. 
Figure 1. Unemployment rates (top panel, reported monthly) and child poverty rates (bottom panel, reported annually) in Massachusetts and the United States.

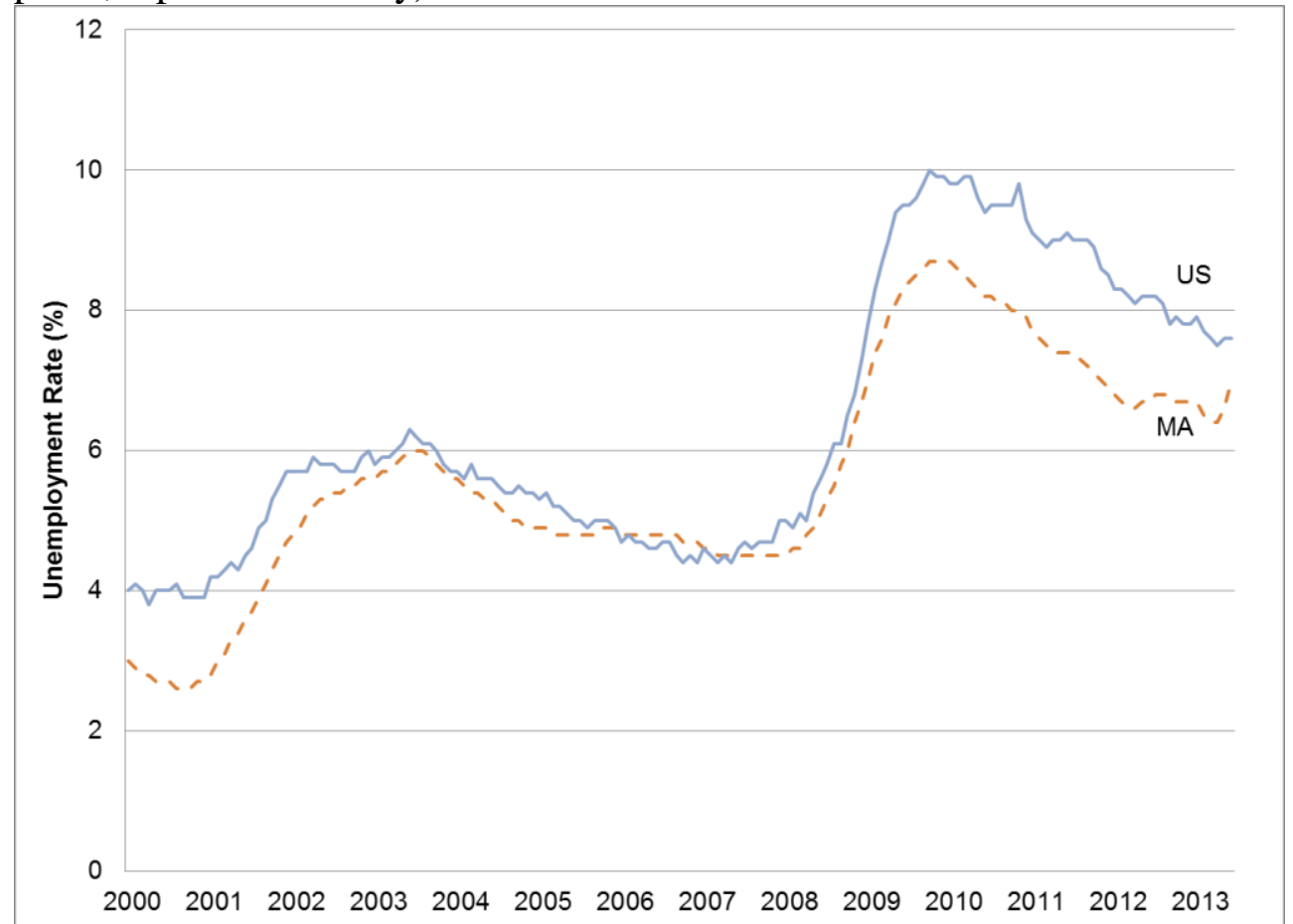

Source: Authors' presentation of data from U.S. Bureau of Labor Statistics available at http://www.bls.gov/lau/data.htm.

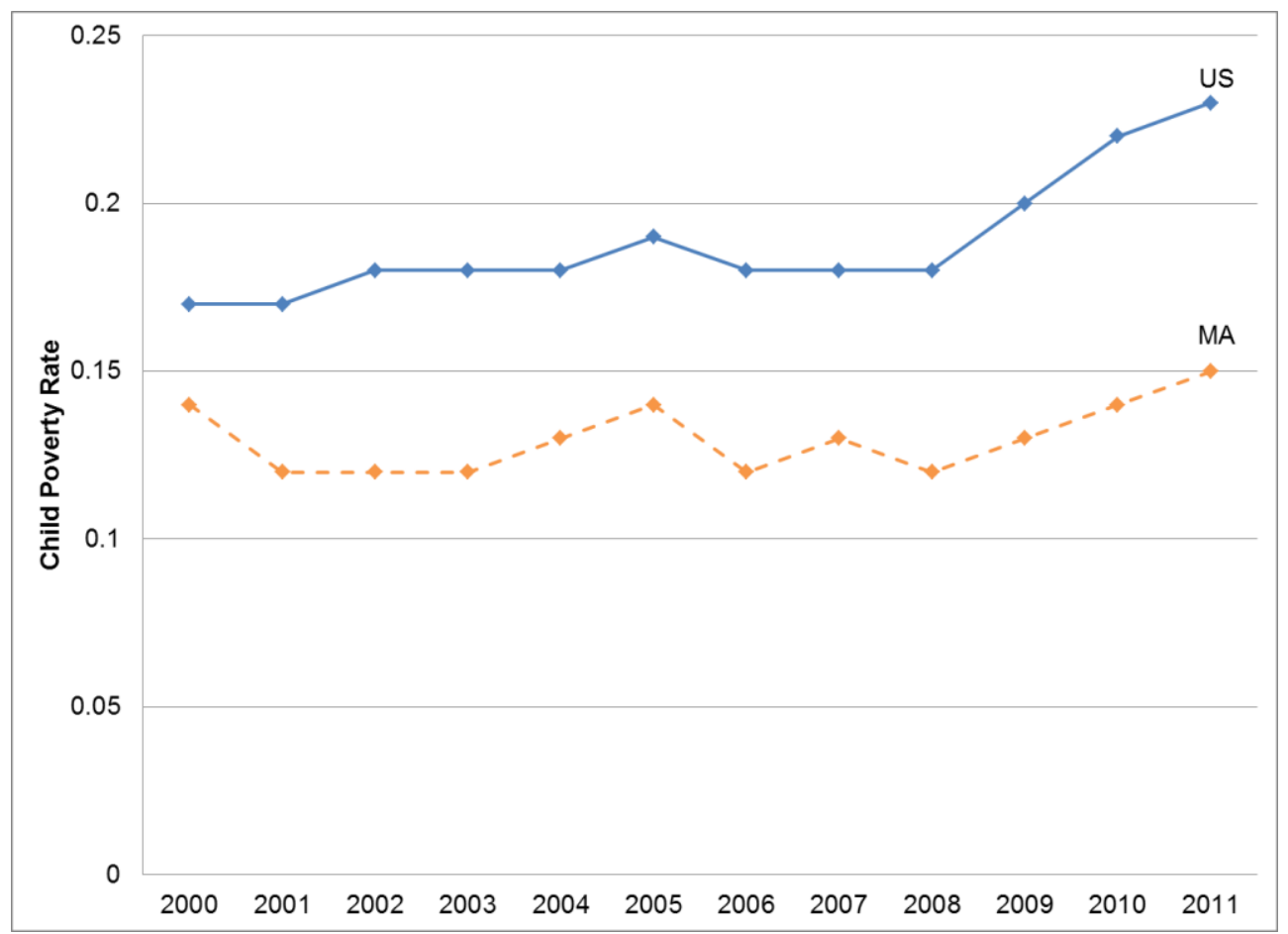

Source: Author presentation of data from KidsCount available at:

http://datacenter.kidscount.org/data/tables/43-children-in-poverty-100-percent-poverty. 
Figure 2. Proportion of students who had achieved each status two years after cohort high-school graduation, for students in the 200203 to $2005-068^{\text {th }}$ grade cohorts.

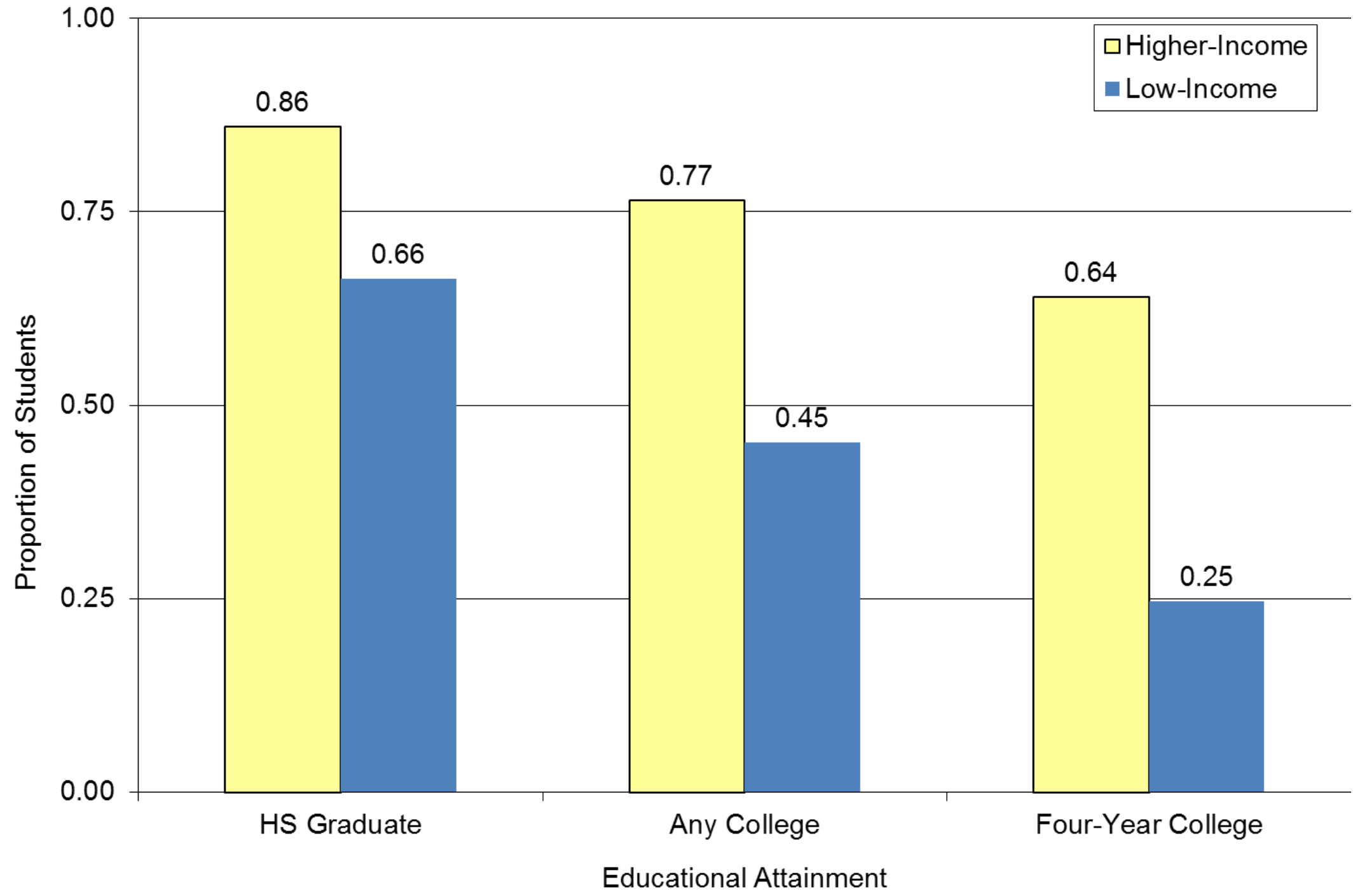


Figure 3. Gap in attainments between low-income and higher-income students in the 2002-03 through 2005-06 8th grade cohorts with defined high school completion outcomes, among students with non-missing values on all covariates.

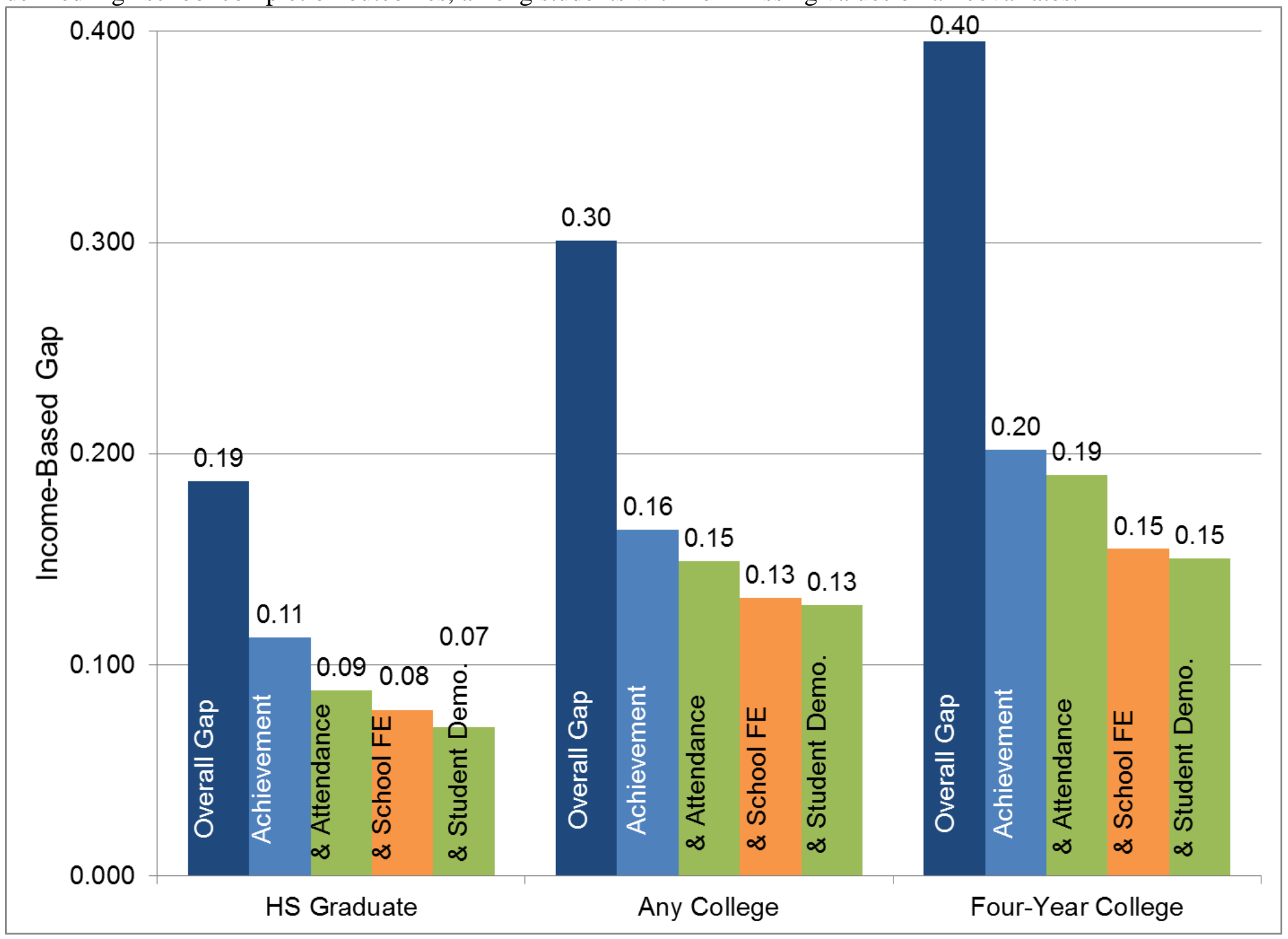


Figure 4. Proportion of low-income students (solid bar) and higher-income students (total bar) in the 2002-03 to 2005-06 $8^{\text {th }}$ grade cohorts who graduate from high school, attend college, and attend a four-year college, with the income-based gap in attainment (striped bar), at different levels of the $8^{\text {th }}$ grade mathematics test-score distribution.

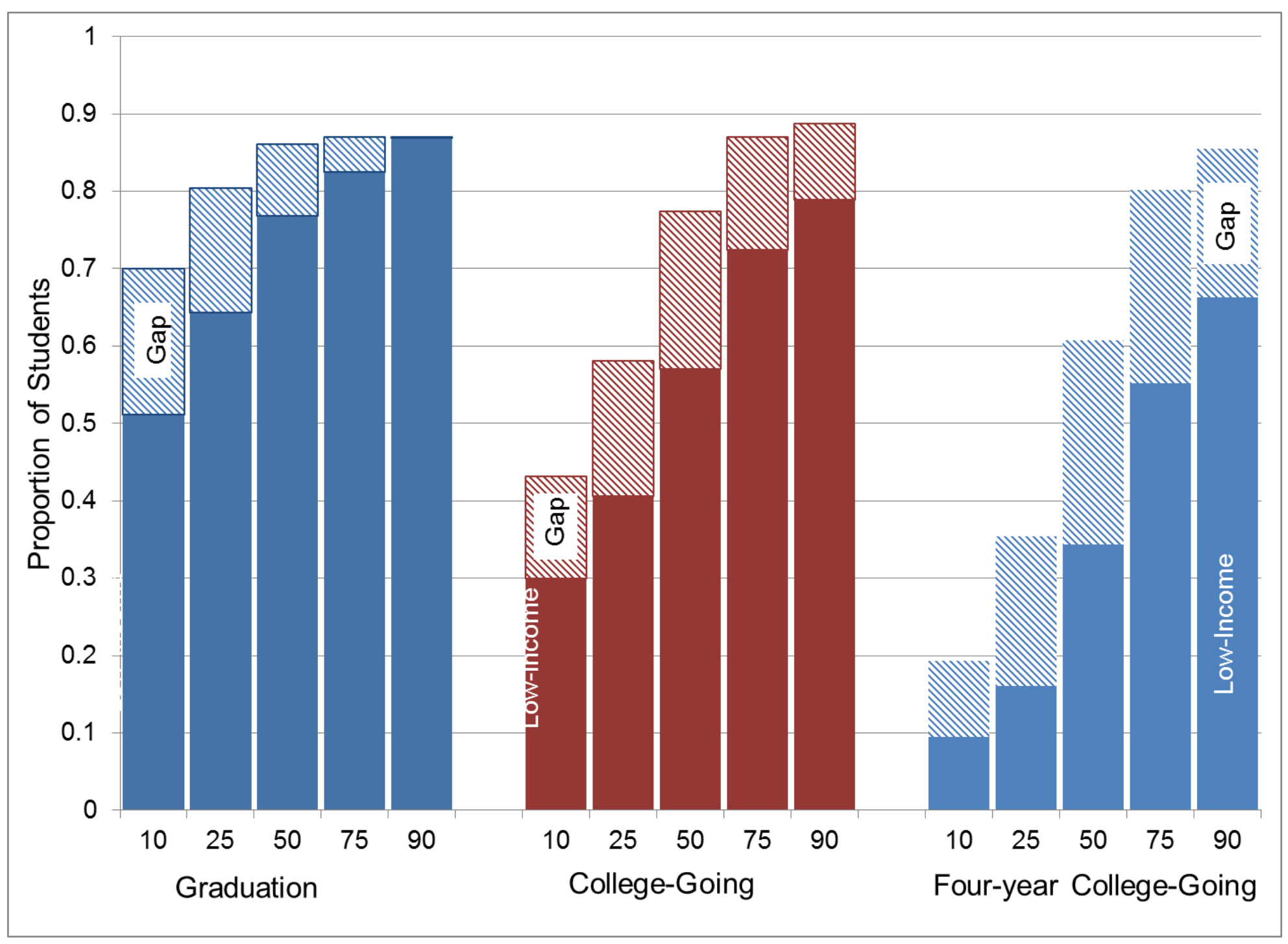


Figure 5. Fitted local linear-regression relationships between the probability of graduating in five years (left panel) or attending college within two years of cohort graduation (right panel) and $10^{\text {th }}$ grade mathematics score relative to the Passing/Failing cutoff $\left(h^{*}=3\right)$, with the sample mean probabilities overlaid, for low-income and higher-income students.
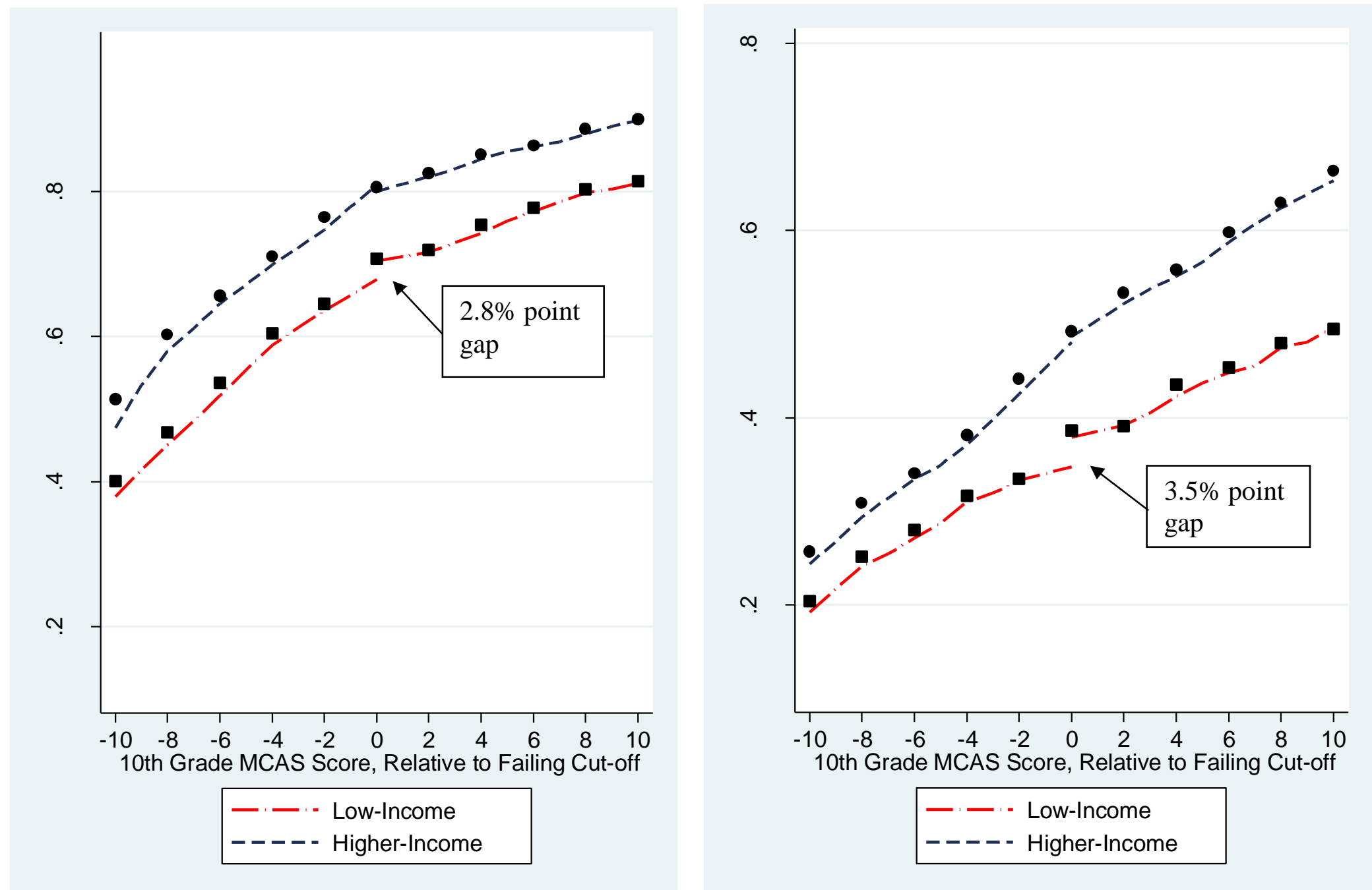
Figure 6. Income-based gaps in four-, five-, and six-year graduation rates, over time (Panel A), overall four-year graduation rate in Massachusetts over time, raw and adjusted (Panel B), and college-going rates over time, by income (Panel C).

Panel A
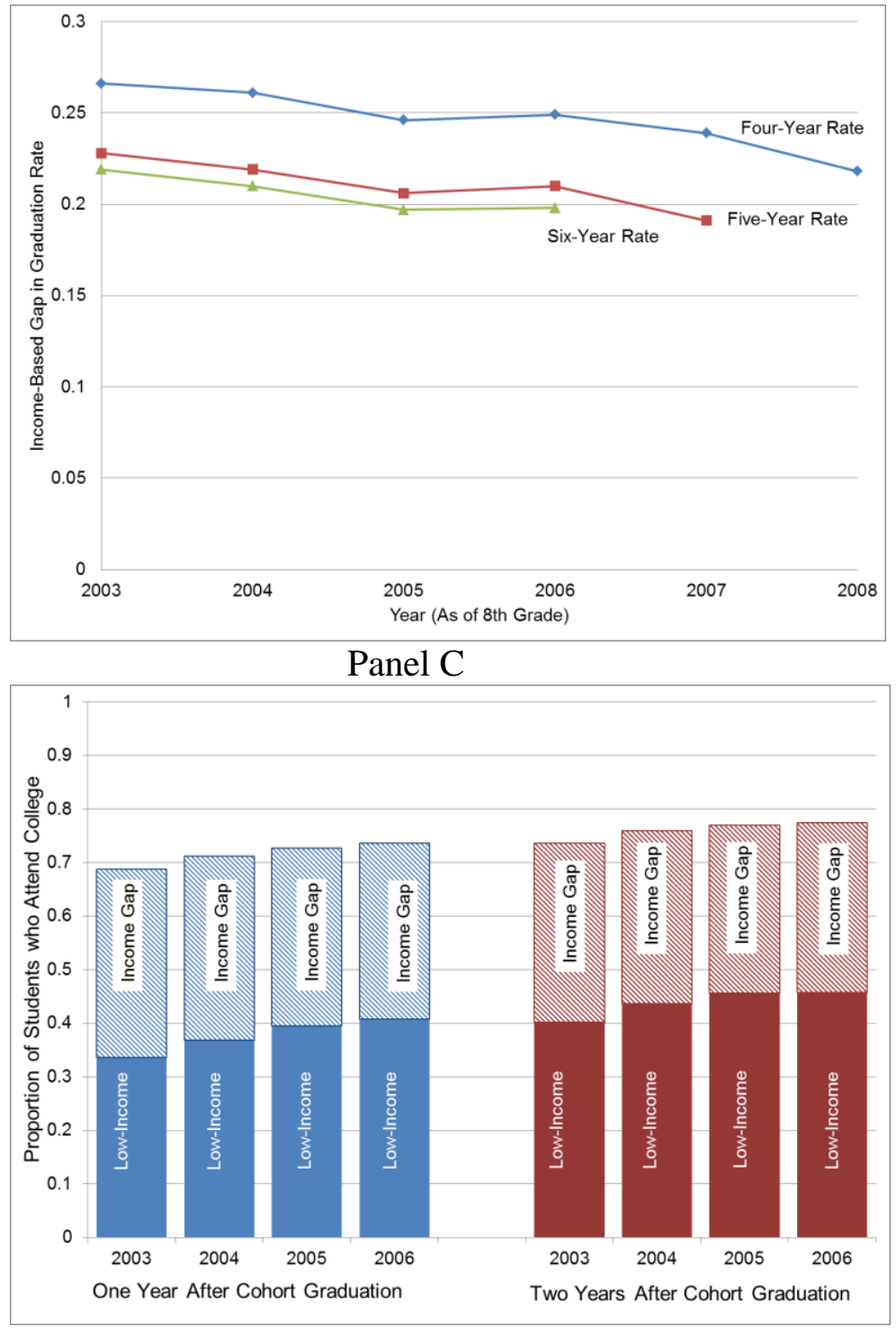

Panel B

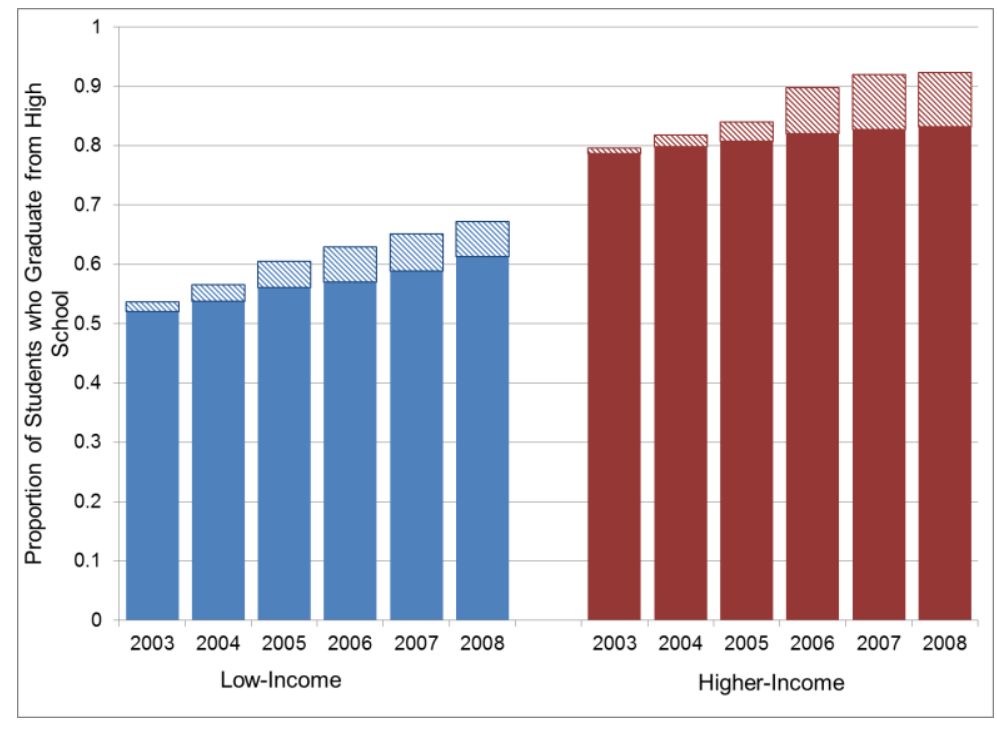


Figure 7. Quantile-Quantile (QQ) plots showing the relationship between the $8^{\text {th }}$ grade mathematics test-score distribution in 2003 and 2011 for low-income students (Panel A) and for higher-income students (Panel B).

\section{Panel A}

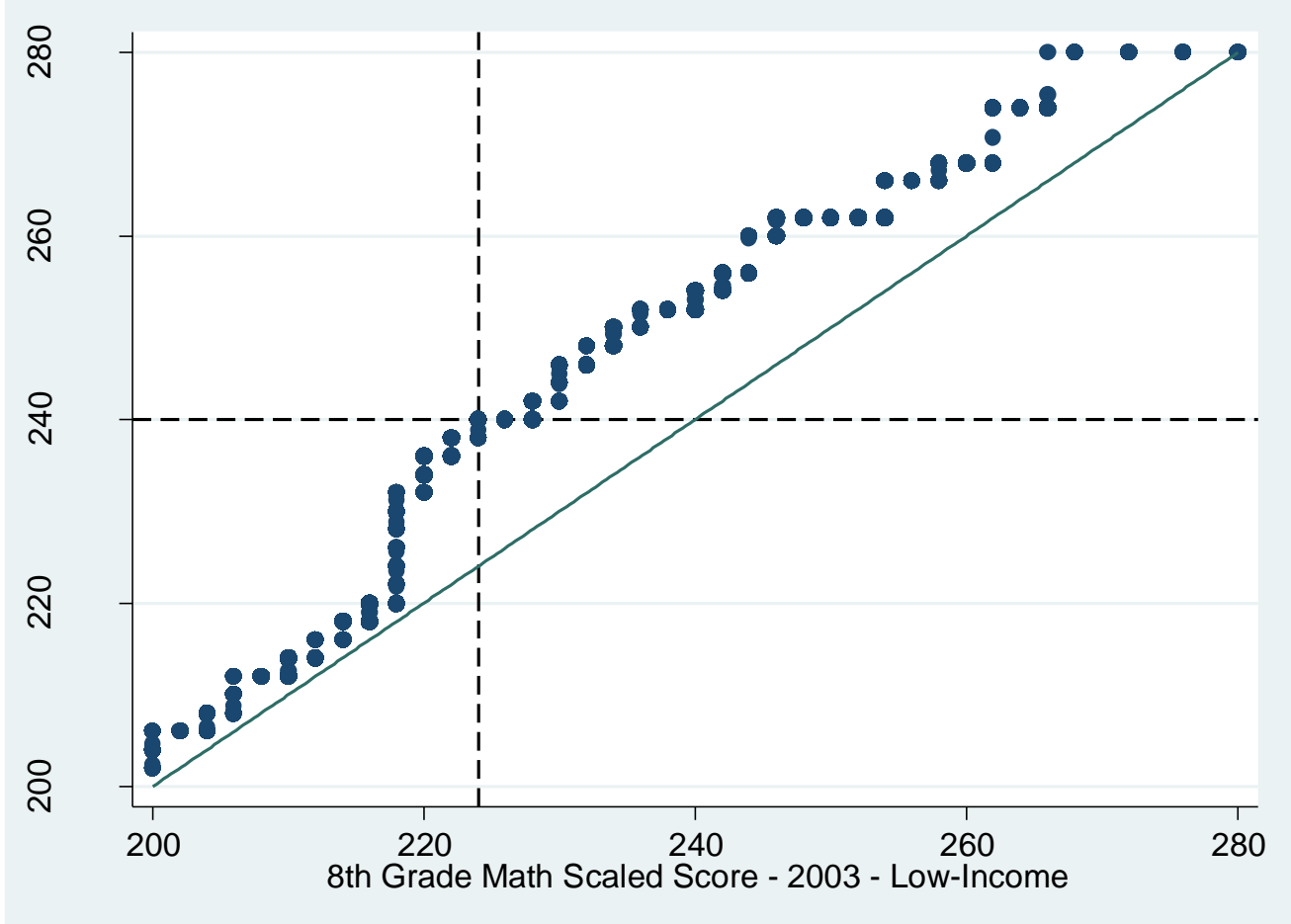

Panel B

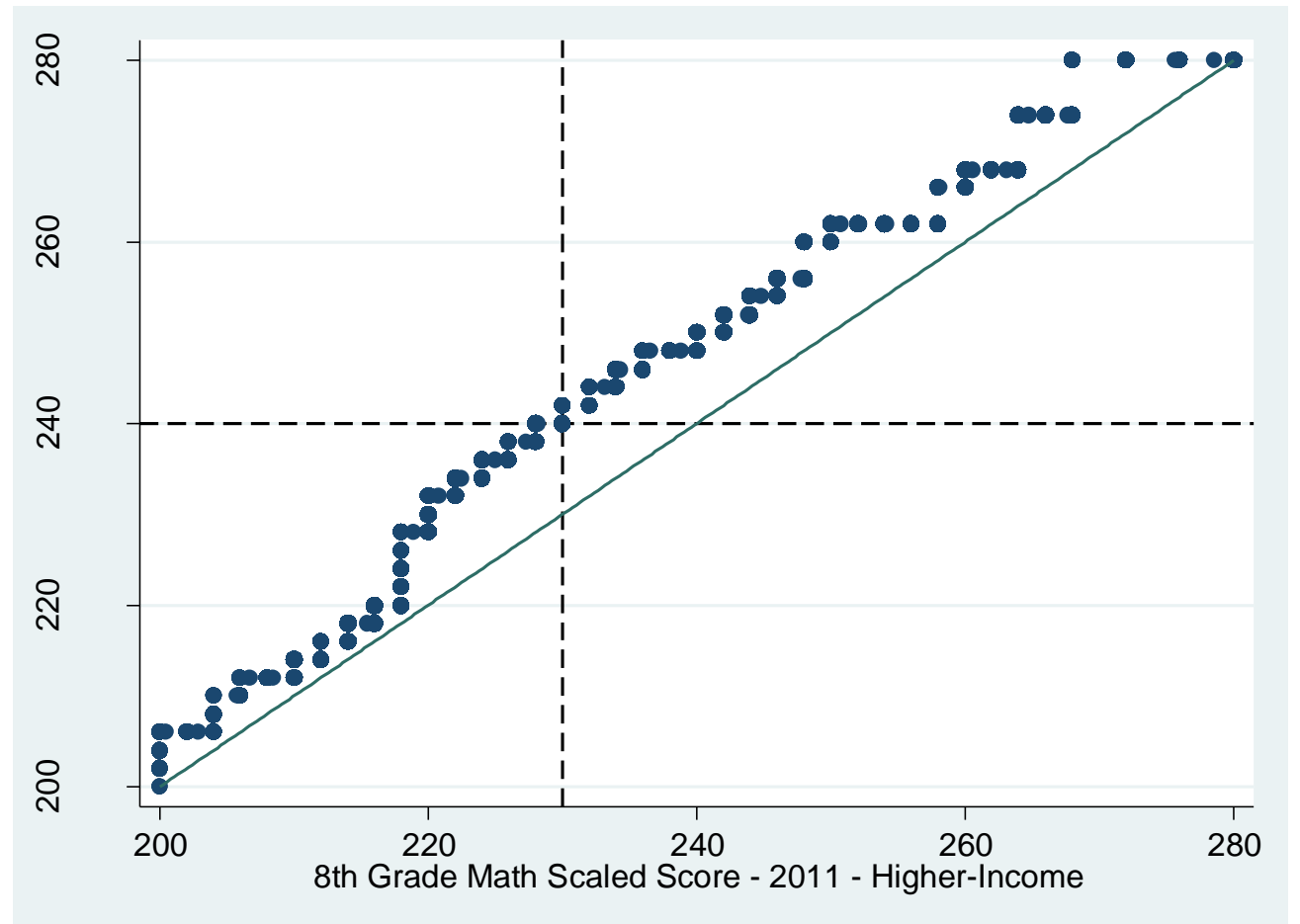


Figure 8. Gaps on the MCAS mathematics tests for cohorts of students entering Massachusetts public schools in different grades.

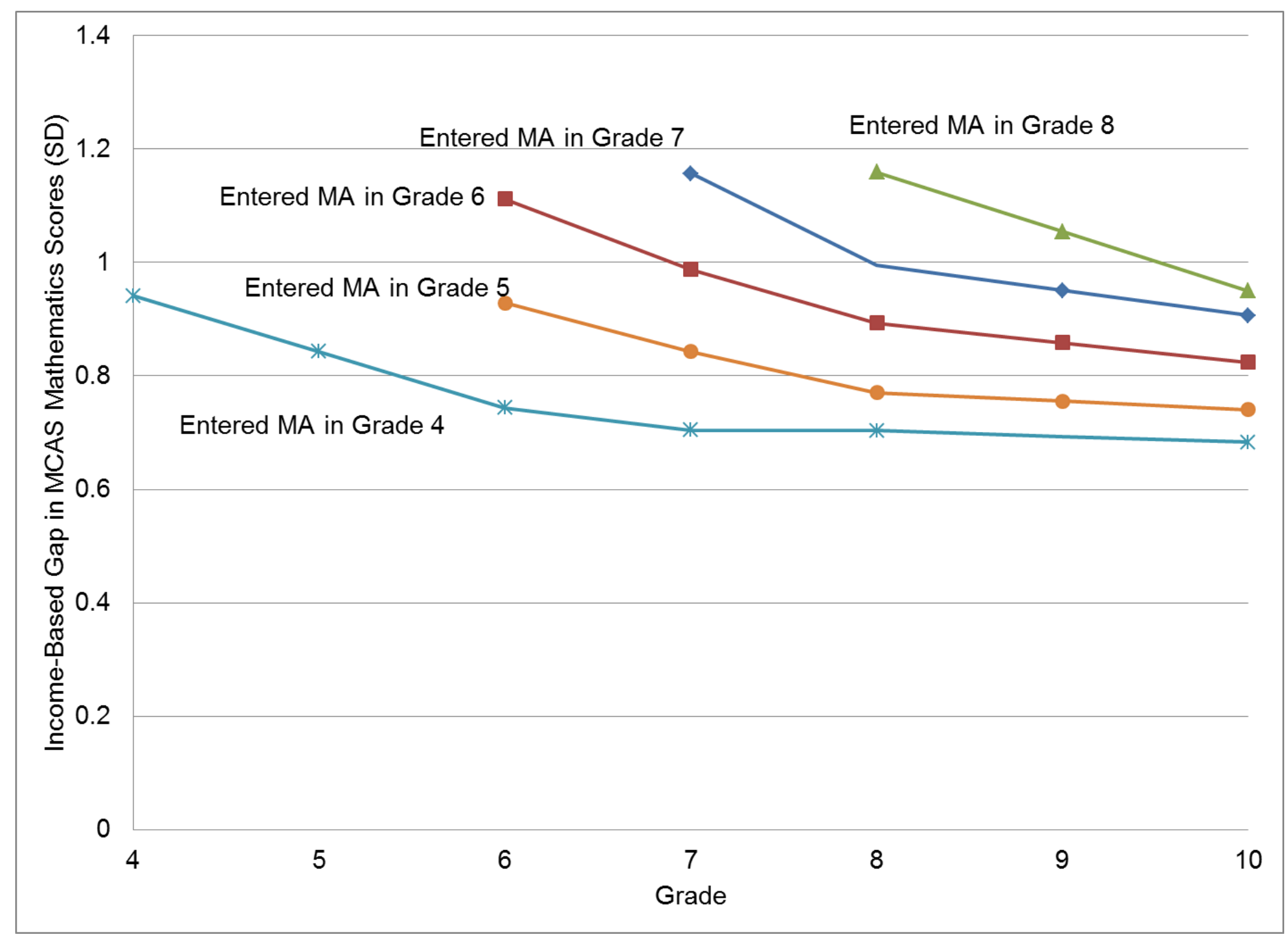


Figure 9. Probability of passing the first attempt on both the $10^{\text {th }}$ grade MCAS examinations in mathematics and English Language Arts, for low-income and higher-income students, over time (top panel) and estimated effect of barely passing (compared to barely failing) the first attempt on the $10^{\text {th }}$ grade MCAS mathematics examination from the regression-discontinuity model in equation (1) for low-income students, over time (bottom panel).
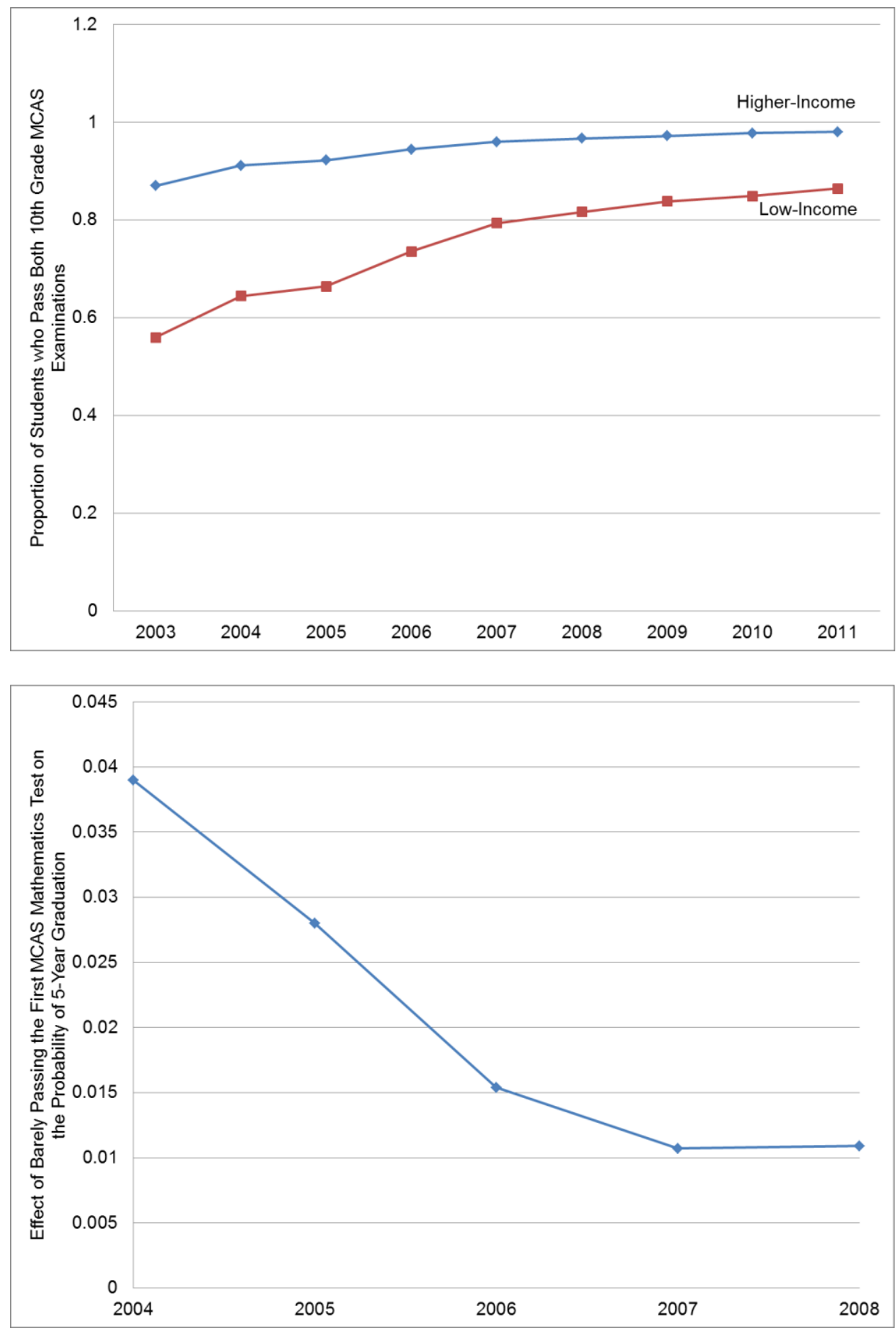
Appendix A. Replication of Figure 6 with an alternative definition of low-income, showing income-based gaps in four-, five-, and sixyear graduation rates, over time (Panel A), overall four-year graduation rate in Massachusetts over time, raw and adjusted (Panel B), and college-going rates over time, by income (Panel C).
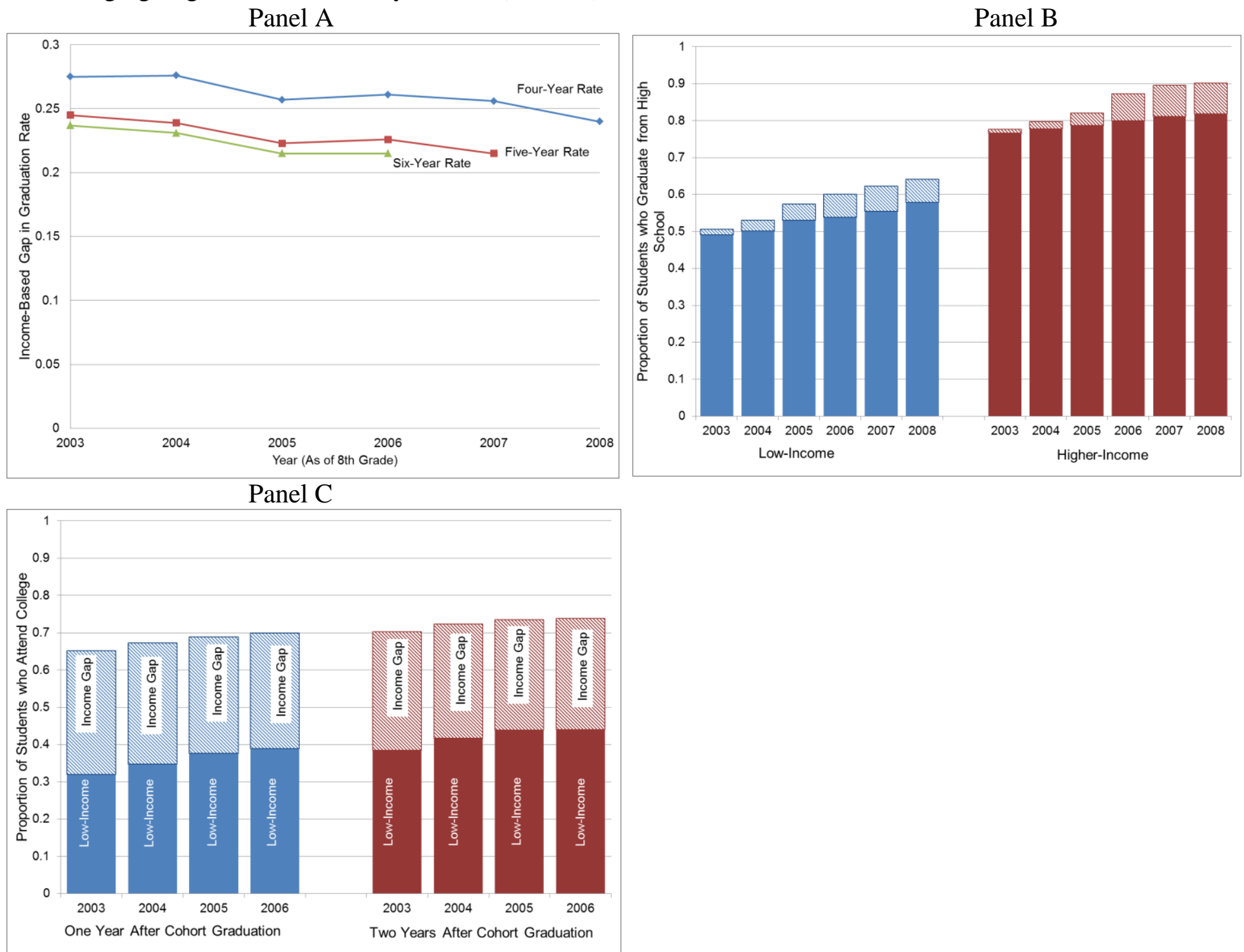